\title{
Phytoplankton community and limnochemistry of Piburger See (Tyrol, Austria) 28 years after lake restoration
}

\author{
Monica TOLOTTI* and Hansjörg THIES \\ Institute of Zoology and Limnology, University of Innsbruck, Technikerstr. 25, A-6020 Innsbruck, Austria \\ *e-mail corresponding author: Monica.Tolotti@uibk.ac.at
}

\begin{abstract}
Phytoplankton community and limnochemistry of Piburger See, a small soft-water, meromictic lake situated at $913 \mathrm{~m}$ a.s.l. in a crystalline area of the Central Eastern Alps of Tyrol (Austria), were investigated 28 years after the beginning of lake restoration. Although long-term data of the lake show a declining trend in total phosphorus concentrations and phytoplankton biovolume, the response of Piburger See to the restoration measures carried out in 1970 was delayed by about 20 years. At present the lake is approaching its former oligotrophic level. The most evident difference between the past and present phytoplankton species composition of Piburger See is the actual absence of the Cyanophycean Oscillatoria limosa C. A. Agardh, which markedly increased during the first two decades after the lake restoration (1970-1987). The phytoplankton biovolume recorded in 1998 was lower than in the 1970s and 1980s, while seasonal patterns were similar to those recorded before and later on in the lake restoration. The lowest annual phytoplankton biovolume in 1998 occurred in early winter, while the absolute maximum was observed in metalimnetic water layers in late spring. In 1998 the intra-annual patterns of phytoplankton biovolume and chlorophyll-a compare well. Phytoplankton succession started in early 1998 under ice with coccal green algae followed by flagellated Chrysophyceae during spring. The mid-summer phytoplankton community was dominated by centric Bacillariophyceae, which were later replaced by coccal Cyanophyceae. During autumn, Dinophyceae and Chrysophyceae prevailed. Epilimnetic dominance of centric diatoms during mid summer appears to be a new feature, which in 1998 was related to a strong depletion of dissolved silica and nitrate. Long-term water chemistry and phytoplankton data were checked against local weather data in order to explain the delay in the re-oligotrophication process of Piburger See. However, no clear relationship could be detected between the trends observed in the lake and weather conditions during the past 30 years.
\end{abstract}

Key words: mountain lakes, phytoplankton, seasonal succession, limnochemistry, long term trends, re-oligotrophication

\section{INTRODUCTION}

Piburger See is a small soft-water lake situated at $913 \mathrm{~m}$ a.s.l. in a crystalline area of the Central Eastern Alps of Tyrol, Austria. The catchment area is small $\left(2.65 \mathrm{~km}^{2}\right)$ and consists mainly of coniferous forest, alpine meadows and bare rocks (Tab. 1). Only ca 5\% of the surrounding area of the lake is used for extensive agriculture (Pechlaner 1979). The high mountains surrounding the lake strongly affect light climate and primary production of the lake (Rott 1986). The water retention time of the lake is about 2 years and the hydrographic balance shows the presence of a significant groundwater inflow ( $\mathrm{ca} 50 \%$, Rott 1976; Gattermayr 1981). The lake is ice-covered from early December to April and is subject to morphogenic meromixis (Pechlaner 1979). After a very short and usually incomplete spring circulation the thermal stability is rapidly reached, with maximum temperature at the surface in July to August (up to $24^{\circ} \mathrm{C}$, Tab. 1). The extension and duration of the autumnal overturn is strongly affected by the weather conditions, in particular by wind (Pechlaner 1979; Gattermayr 1981).

At present Piburger See is an oligo-mesotrophic lake, but during the 1950s and 1960s it has suffered from eutrophication due to increasing use of the lake for recreational activities and application of artificial fertilizer on nearby meadows (Pechlaner 1968, Tab. 2). The eutrophication process became evident through the increase of primary production and strong hypolimnetic oxygen depletion (Pechlaner 1979). During the winter $1969 / 70$, almost the whole lake became anoxic, threatening to cause massive fish death (Pechlaner 1971a).

In 1970, a lake restoration was initiated by reducing the external nutrient loading (waste water deviation and reduction of the application of artificial fertilizers) and by increasing nutrient export through hypolimnetic water withdrawal (installation of an Olszewski tube, Psenner et al. 1984).

The oxygen regime of the lake improved markedly and rapidly after the selective removal of the anoxic hypolimnetic water by the Olszewski tube has started (Mayrhofer 1975; Pechlaner 1979). However, hypolimnetic oxygen saturation (Fig. 1A) became worse again, especially during the 1980 s in winter, due to a progressively reduced discharge of the tube (Psenner 1988). The oxygen saturation levels did finally recover by the replacement of the tube in the early 1990s (Psenner et al. 1998).

The effects of the lake restoration on nutrient concentrations and phytoplankton biovolume were delayed by approximately 2 decades with respect to the start of 
lake restoration (Pechlaner 1979; Rott 1983; Pipp \& Rott 1995; Psenner et al. 1994, 2000). After the installation of the Olszewski tube, even an increase in phytoplankton biomass, accompanied by a decrease in the Secchi depth (Fig. 1B) and by an increase in chlorophyll- $a$ and total phosphorus, was observed (Fig. 2). The period 1970-1988 was characterised by a marked increase in the development of the filamentous blue green alga Oscillatoria limosa C.A. Agardh, which became the dominant algal taxon in the lake, contributing up to $40 \%$ of the annual mean of total phytoplankton biovolume in 1974 (Rott 1976).

Tab. 1. Geographical, morphological and physico-chemical characteristics of Piburger See. * = mean of monthly weighted averages for the period 1975-1999.

\section{GEOGRAPHICAL CHARACTERISTICS}

Position: Ötztal, Tyrol, Austria

Latitude: $45^{\circ} 11^{\prime} 30^{\prime \prime} \mathrm{N}$

Longitude: $10^{\circ} 53^{\prime} \mathrm{E}$

Altitude: $913 \mathrm{~m}$ a.s.1.

Catchment area: $2.65 \mathrm{~km}^{2}$

Altitudinal gradient within the catchment: 913 - $2268 \mathrm{~m}$ a.s.l.

Geology: crystalline (granodiorite-biotitgranitegneis)

Land cover: forest $(60 \%)$, alpine meadow and bare rock $(35 \%)$, agriculture $(5 \%)$

\section{MORPHOMETRIC CHARACTERISTICS}

Lake area: 13.4 ha

Maximum length: $0.8 \mathrm{~km}$; Maximum width: $0.3 \mathrm{~km}$

Lake shore development: 1.5

Maximum depth: $24.6 \mathrm{~m}$

Mean depth: $13.7 \mathrm{~m}$

Volume: $1.810^{6} \mathrm{~m}^{3}$

Retention time: $c a 2$ years

Ice formation: early December-late December

Ice break up: late March - early May

\section{PHYSICO-CHEMICAL CHARACTERISTICS}

Conductivity*: ca $70 \mu \mathrm{S} \mathrm{cm}{ }^{-1}$

$\mathrm{pH}^{*}: 7$

Alkalinity*: $c a 450 \mu$ eq $1^{-1}$

Maximum water temperature: up to $24^{\circ} \mathrm{C}$ in July-August

Present trophic status: oligo - oligomesotrophic (Vollenweider \& Kerekes 1982)

The re-oligotrophication of Piburger See began only during the late 1980s (Psenner et al. 1994; Pipp \& Rott 1995), several years after the waste-water diversion in 1970 (Psenner et al. 1984).

Since the beginning of the 1970s, when the restoration measures were started, Piburger See has been under investigation by the University of Innsbruck. The research program included chemical analyses, which are important for the assessment of the long-term trends of water quality. The phytoplankton of the lake was regularly investigated from the late 1960s to the beginning of the $1980 \mathrm{~s}$, but these studies were stopped until the late 1990s. The understanding of long-term variations in the nutrient concentrations is hindered by the irregular frequency of the phytoplankton community investigations. For this reason, a new detailed study of phytoplankton of Piburger See has been carried out as part of the EU-Project REFLECT (ENV4-CT97-0453) in 1998.
Tab. 2. Trends of Piburger See.

\begin{tabular}{|c|c|}
\hline 1950's: & Oligotrophic mountain lake. \\
\hline 1960’s: & $\begin{array}{l}\text { Increase of the nutrient concentrations due to } \\
\text { agricultural activities in the catchment and diffuse } \\
\text { inputs of domestic waste-waters. }\end{array}$ \\
\hline Winter 1969/70: & $\begin{array}{l}\text { Strong oxygen depletion from the bottom of the } \\
\text { lake up to } 3 \mathrm{~m} \text { depth. }\end{array}$ \\
\hline Summer 1970: & $\begin{array}{l}\text { Beginning of lake restoration measures: diversion } \\
\text { of waste-waters, stop of the use of chemical } \\
\text { fertilizers, installation of an Olszewski tube for the } \\
\text { withdrawal of the nutrient rich deep water. }\end{array}$ \\
\hline Until late 1980 's: & $\begin{array}{l}\text { Recovery of the oxygen saturation in the deep- } \\
\text { water layers. No clear effect of the restoration on } \\
\text { nutrient level, phytoplankton biovolume and } \\
\text { species composition. }\end{array}$ \\
\hline Since late 1980 's: & $\begin{array}{l}\text { Reduction of phosphorus; decrease of the } \\
\text { filamentous blue-green algae Oscillatoria limosa in } \\
\text { the open water. }\end{array}$ \\
\hline Since 1990: & $\begin{array}{l}\text { Change of the summer phytoplankton species } \\
\text { assemblage from green/filamentous blue-green to } \\
\text { diatoms/coccal green algae. }\end{array}$ \\
\hline
\end{tabular}

\section{METHODS}

During 1998, monthly samplings were carried out at the deepest point of Piburger See. On each occasion, water samples for chemical and biological analyses were taken with a Patalas-Schindler sampler every 3 meters from 0 to $24 \mathrm{~m}$ depth. Water temperature was measured with a thermometer inside the sampler. Chemical analyses, including measurements of oxygen concentration and saturation (Winkler's method), $\mathrm{pH}$ and conductivity, alkalinity (Berger's method), major ions (ion chromatography) and nutrient concentrations, were carried out in the laboratory. Concentrations of ammonium and nitrate nitrogen were determined spectrophometrically after reaction with sodium salicilate and reduction with sodium salicilate Seignette salt respectively. Soluble reactive phosphorus (SRP) was determined by spectrophotometry using the molybdate method. Total phosphorus (TP) was analysed with the same method after digestion with potassium persulphate. Soluble reactive Silica was determined by spectrophotometry after reaction with molybdate. The chlorophyll- $a$ concentration was determined spectrophotometrically after filtration through glass fibre filters (Whatman GF/F) and extraction in acetone 90\% (Jeffrey \& Humphrey 1975).

Out of the phytoplankton samples taken monthly during 1998 (preserved with acidic Lugol's solution), 11 series could be analysed qualitatively and quantitatively, while samples from June 1998 are lacking. Phytoplankton biovolume was estimated from measurements of samples counted by Utermöhl's method (1958), using an inverted microscope Zeiss Axiovert 135 with phase contrast. At each magnification at least 100 individuals of the most frequent taxon were counted, thus ensuring a statistical error less than $20 \%$ (Lund et al. 1958). Individual cell volumes of the different taxa were calculated approximating the cell shapes to simple geometrical 


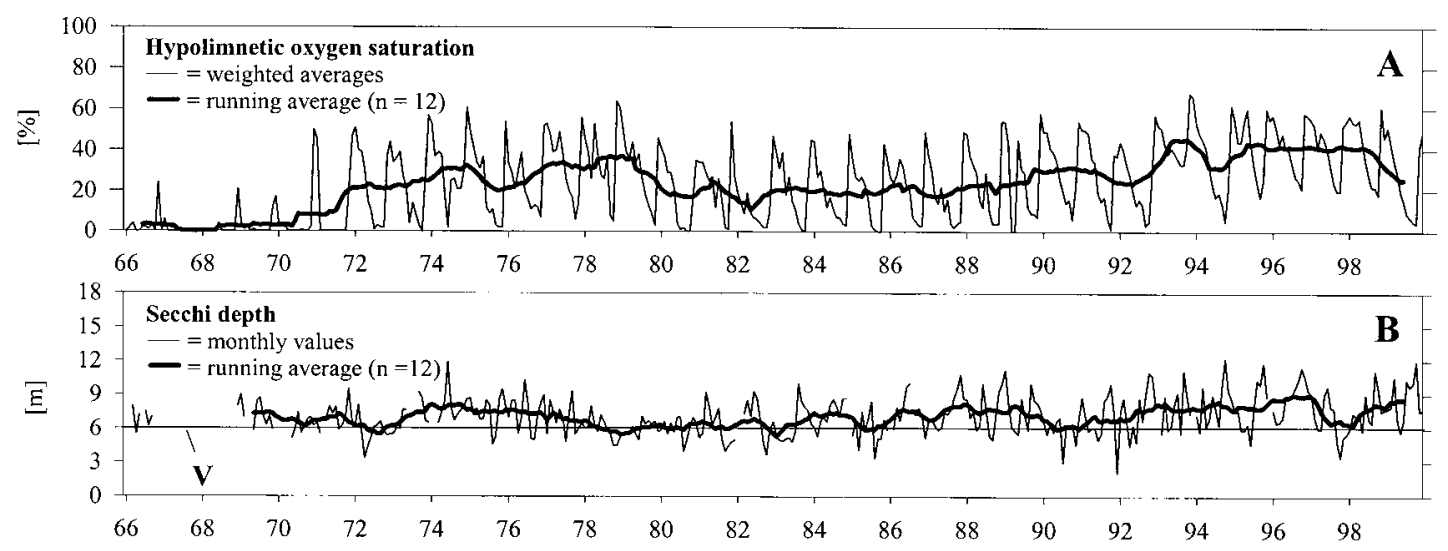

Fig. 1. Long term trends in Piburger See from 1966 to 1999. Horizontal line in Fig. 6/B represents the threshold between oligotrophic and meso- eutrophic conditions according to Vollenweider \& Kerekes 1982 (= V).
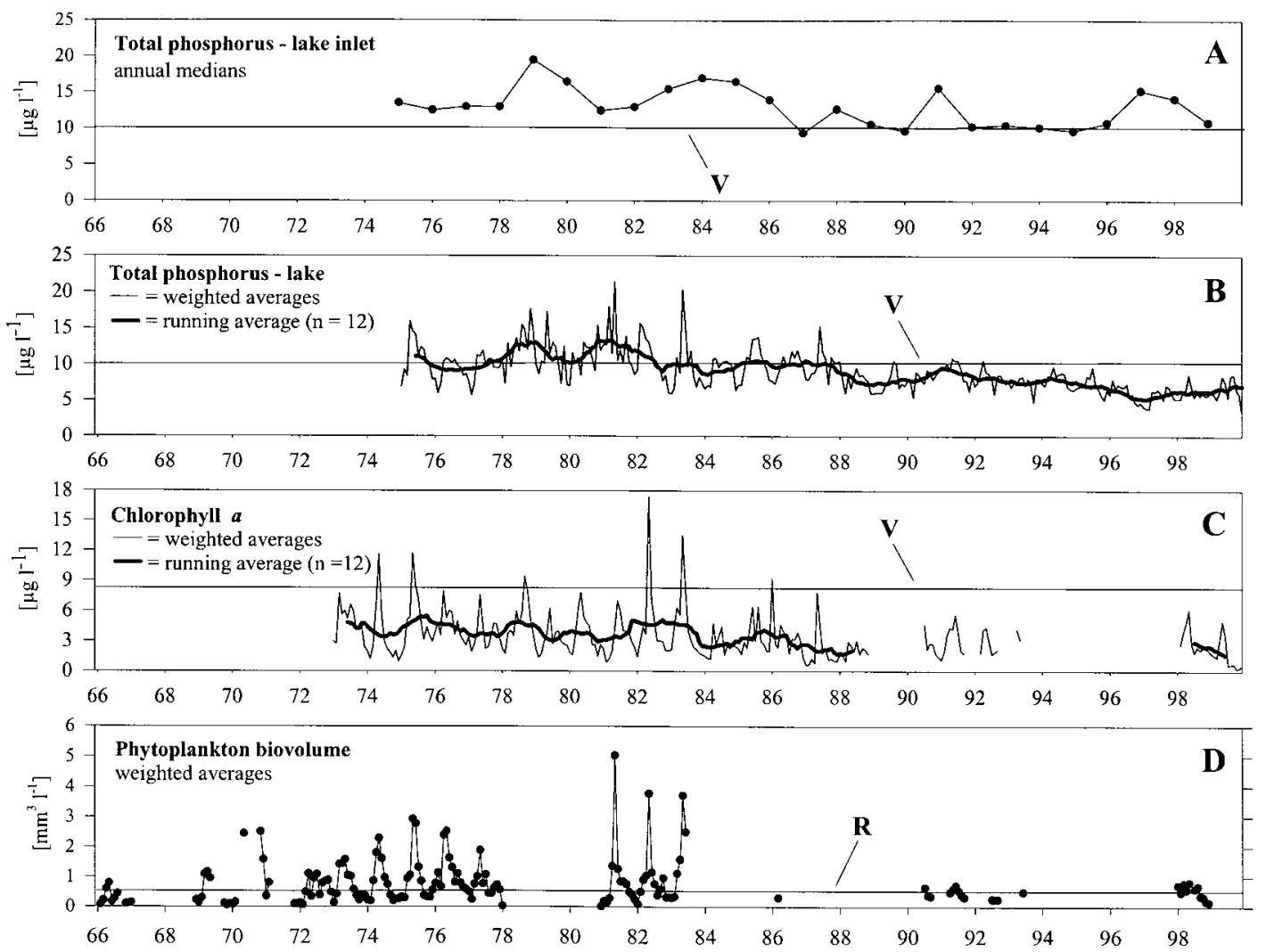

Fig. 2. Long term trends in Piburger See from 1966 to 1999. Horizontal lines represent the threshold between oligotrophic and mesoeutrophic conditions according to Vollenweider \& Kerekes 1982 (= V) and Rott 1984 (= R).

bodies (Rott 1981) and applying, when possible, the same criteria used in previous studies (Rott 1983; Prader 1993).

\section{RESULTS}

\subsection{Limnochemistry}

The distribution of water temperature in Piburger See indicated two overturn periods during 1998. The spring circulation that occurred in March (Fig. 3A) was short and partial, as is typical for Piburger See (Pechlaner 1979). The late autumn circulation was complete and more prolonged (late November to early December, Fig. 3A). An inverse stratification occurred during winter under the ice cover, while from April to the early November a stable stratification developed, with a maximum extension of the epilimnion down to $15 \mathrm{~m}$ at the end of October. The highest temperature recorded at the lake surface was $21.5{ }^{\circ} \mathrm{C}$ in July. The stable temperature stratification in summer (average 
Schmidt stability of the whole water column from May to October $=2392 \mathrm{~J} \mathrm{~m}^{-2}$ ) led to a clear oxygen depletion in the deep water layers, with oxygen saturation values lower than $20 \%$ close to the lake sediments (Fig. 3B). In contrast, oxygen super-saturation was recorded in the epilimnion from May to September 1998 (up to 160\% at $9 \mathrm{~m}$ in July and August, Fig. 3B), which is related to the phytoplankton photosynthetic activity.
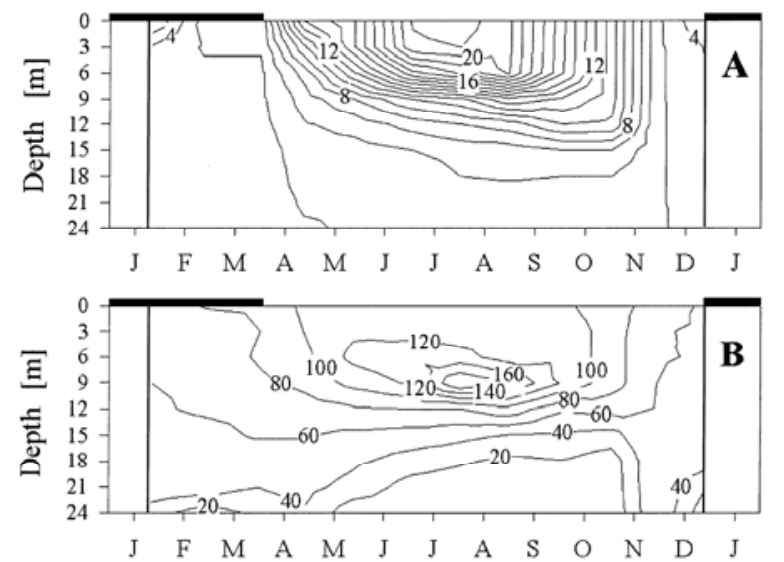

Fig. 3. Water temperature (A) and oxygen saturation (B) in Piburger See in 1998. - = ice cover.

The thermal evolution of Piburger See influences both the temporal and spatial distributions of other physical and chemical parameters. As recorded in several European high mountain lakes (The MOLAR Water Chemistry Group 1999; Thies et al. 2000), the conductivity of Piburger See $\left(62-84 \mu \mathrm{S} \mathrm{cm}^{-1}\right)$ appears to be affected by the snowmelt, which dilutes the solutes in the upper water layers in spring (Psenner et al. 2000). The higher conductivity values recorded in the deep water during the stratification periods are probably due to ion release from the sediments. The effect of the snowmelt was evident also on alkalinity (median $=466 \mu \mathrm{eq} \mathrm{l}^{-1}$ ), which showed a certain decrease at the surface in early spring (Psenner et al. 2000). The higher values recorded in the deep water during the two stratification periods (up to $630 \mu \mathrm{eq} \mathrm{l}^{-1}$ ) are due to internal abiotic and biotic alkalinity generation processes, occurring in the poorly oxygenated water near to the lake sediments (Psenner 1988; Thies 2000).

The $\mathrm{pH}$ values recorded in Piburger See in 1998 ranged between 6.5 and 8.7 (Psenner et al. 2000). The highest $\mathrm{pH}$ values, recorded in the epilimnion in July, were related to increased chlorophyll a concentrations, while the lowest ones were recorded in the anoxic water layers near the lake sediments.

With regard to the nutrient concentrations, nitrate $\left(\mathrm{NO}_{3}-\mathrm{N}\right.$, median $\left.=77 \mu \mathrm{g} \mathrm{l}^{-1}\right)$ showed relatively high values (up to $189 \mu \mathrm{g}^{-1}$ ) at the surface in late winter 1998 (Fig. 4A). This has been recorded also in other mountain brooks and lakes (Thies et al. 1998; Thies et al. 2000) and can be explained as a consequence of the increased release from the seasonal snow pack during early thaw (Nickus et al. 1998). During summer nitrate concentrations were lower than $c a 50 \mu \mathrm{g} \mathrm{l}^{-1}$ in the upper $9 \mathrm{~m}$ of the water column and near the bottom (Fig. 4A). This feature is related to algal growth in the epilimnion and to microbial reduction processes under anoxic conditions in the hypolimnion (Fig. 3B). Ammonia concentrations showed an inverse pattern in comparison to nitrate. Values between 400 and $1000 \mu \mathrm{g} \mathrm{l^{-1 }} \mathrm{NH}_{4}-\mathrm{N}$ were found only below $18 \mathrm{~m}$ depth during summer and winter stratification periods (Psenner et al. 2000).
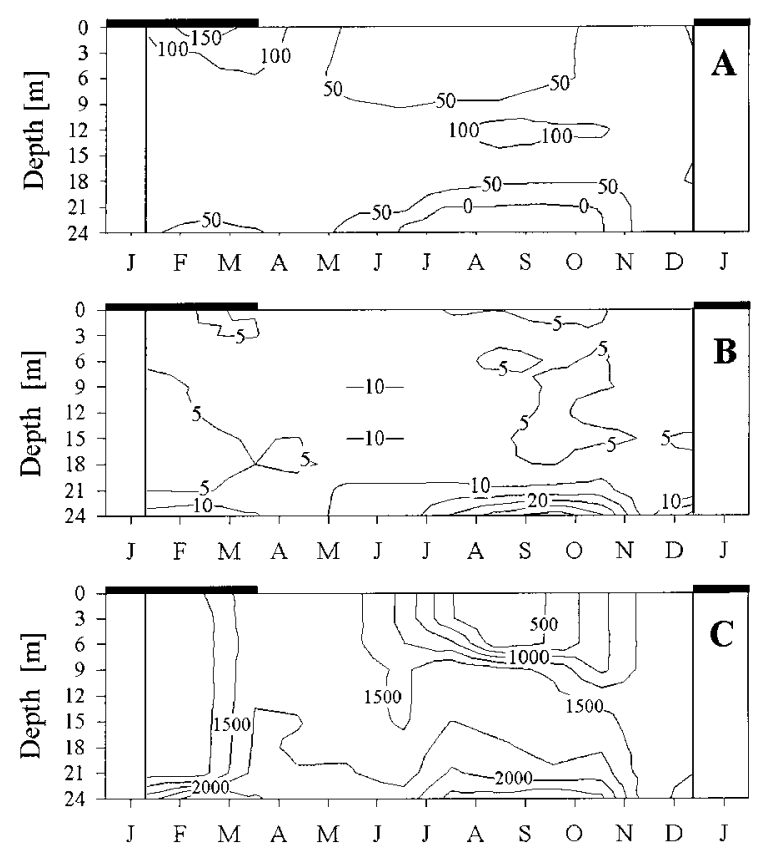

Fig. 4. Nitrate nitrogen (A), total phosphorus as $\mathrm{P}(\mathbf{B})$ and silica as $\mathrm{Si}(\mathbf{C})$ in Piburger See in 1998. - = ice cover.

TP concentrations (Fig. 4B) were lower than $5 \mu \mathrm{g}^{-1}$ in the upper $18 \mathrm{~m}$ of the lake during the whole year of 1998. The increase in TP observed in the deep water in summer (up to $34 \mu \mathrm{g}^{-1}$ at $24 \mathrm{~m}$ in September) was likely due to phytoplankton sedimentation as well as to decomposition processes. The high TP concentrations found in the metalimnion in late spring 1998 (Fig. 4B) reflects the strong development of flagellated planktonic algae in these water layers, as typical for Piburger See (cf. Findenegg 1968; Rott 1983).

Silica concentrations $\left(\right.$ median $\left.=1490 \mu \mathrm{g} \mathrm{l}^{-1}\right)$ showed in 1998 a very pronounced decrease in the epilimnion from July to November, with lowest values ( $\mathrm{ca} 250 \mu \mathrm{g}$ $\mathrm{l}^{-1}$ ) in August in the upper $6 \mathrm{~m}$ of the lake (Fig. 4C). This progressive depletion of silica is likely the consequence of an intense assimilation by centric diatoms, which strongly developed in the epilimnion in mid summer 1998. 
Chlorophyll- $a$ concentrations ranged in 1998 between 3 and $13 \mu \mathrm{g} \mathrm{l}^{-1}$ and were almost uniformly distributed along the water column during the autumn mixing period (Fig. 5A). The high values recorded in the metalimnion in late spring are related to the characteristic vertical distribution of phytoplankton in Piburger See during this period (Rott 1983; Prader 1993). The maximum concentrations recorded in the hypolimnion in late summer and autumn were related to higher TP concentrations (Fig. 4B) and were probably a consequence of sedimentation and light adaptation processes of phytoplankton during the summer stratification. Secchi depths varied during 1998 from 5.5 to $12 \mathrm{~m}$ (Fig. $5 \mathrm{~B})$, with minimum and maximum values in accordance with the vertical distribution of the chlorophyll concentrations (Fig. 5A).

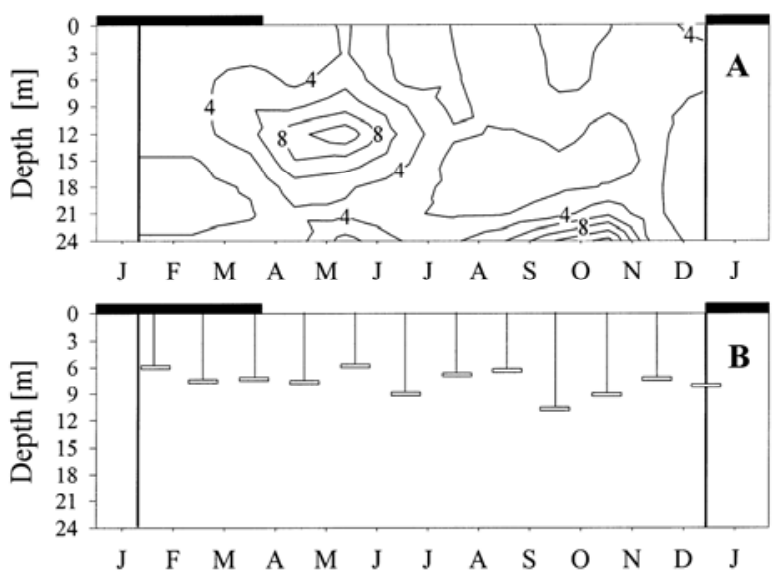

Fig. 5. Chlorophyll- $a(\mathbf{A})$ and Secchi depth (B) in Piburger See in 1998. $-=$ ice cover.

The annual ranges of monthly weighted averages of TP concentrations (5.2-8.6 $\left.\mu \mathrm{g} \mathrm{l}^{-1} \mathrm{P}\right)$ and chlorophyll- $a$ (1.8-6 $\left.\mu \mathrm{g} \mathrm{l}^{-1}\right)$ and the monthly values of Secchi depth (5.5 - $12 \mathrm{~m}$ ) in 1998 place Piburger See within the class of oligotrophy (Vollenweider \& Kerekes 1982).

\subsection{Phytoplankton species composition}

The phytoplankton assemblage of Piburger See in 1998 was composed of 96 taxa, the most frequent of them are listed in table 3. Flagellated and coccal Chlorophyceae were the group most rich in species, followed by Chrysophyceae, Cyanophyceae, Dinophyceae and Cryptophyceae. All other algal groups were represented by very few taxa (Tab. 3). $52 \%$ of the taxa identified were flagellated, as typical for mountain lakes, which are ice covered for several months per year and where the motility represents an important advantage for planktonic organisms (Pechlaner 1971b; Tilzer 1972; Rott 1988).

The phytoplankton species composition found in Piburger See in 1998 did not substantially differ from that reported in previous investigations carried out both before and since the lake restoration (Findenegg 1968; Rott 1983; Prader 1993). Three taxa found for the first time in Piburger See occurred occasionally in the samples of 1998: Katablepharis sp. Skuja, Chrysolykos planctonicus Mack and Eutetramorus fottii (Hindák) Komárek (Tab. 3). The most important difference between the present and past phytoplankton assemblages is the observed absence of the filamentous Cyanophycea Oscillatoria limosa C. A. Agardh in all the samples taken in 1998. During the first two decades after the lake restoration (1970-1987), this blue-green alga markedly increased in Piburger See, contributing up to $40 \%$ of the annual mean of total phytoplankton biovolume in 1974 (Rott 1976). This species showed meroplanktonic behaviour in Piburger See, with a complex life cycle including a planktonic stage from late winter to mid summer only (Rott 1976; Rott 1991). After ice out Oscillatoria limosa used to grow in mid depth waters (12$15 \mathrm{~m}$ ) at low temperature and low light intensity (Rott 1976), forming a summer bloom from May to July (Rott 1991). Since early August Oscillatoria limosa used to disappear from the pelagial starting the bethonic stage of its life cycle.

In 1998, several coccal Cyanophyceae, like Aphanothece clathrata W. \& G. S. West, Chroococcus limneticum Lemmermann, Microcystis incerta (Lemm.) Starmach and Snowella litoralis (Häyrén) Komárek \& Hindák, were clearly more abundant than the filamentous taxa, among which only Lyngbya limnetica Lemmermann was relatively common in the hypolimnion during autumn (Fig. 7D).

\subsection{Phytoplankton seasonality}

All weighted averages of total phytoplankton biovolume determined from the samples taken during 1998 were lower than $1 \mathrm{~mm}^{3} \mathrm{l}^{-1}$ (Fig. 6), which is considered by Heinonen (1980) as threshold line between oligoand mesotrophic conditions. According to Rott (1984), only the autumnal weighted averages fall clearly within the range of oligotrophy (biovolume $<0.5 \mathrm{~mm}^{3} \mathrm{l}^{-1}$ ). The biovolumes recorded in 1998 were lower than in the past, especially in comparison to the 1970's and 1980's, when phytoplankton biomass reached very pronounced peaks in spring and early summer (up to $5 \mathrm{~mm}^{3} \mathrm{l}^{-1}$ in May 1981). The highest weighted averages of phytoplankton biovolume were recorded in winter, spring (annual maximum of $c a 0.8 \mathrm{~mm}^{3} \mathrm{l}^{-1}$ in May) and mid summer (Fig. 6), while the annual minimum occurred in late December $\left(0.15 \mathrm{~mm}^{3} \mathrm{l}^{-1}\right)$. This annual distribution of phytoplankton was very similar to that recorded in Piburger See in the past before and after the beginning of the lake restoration (Findenegg 1968; Rott 1983; Prader 1993). Chlorophyceae, Cyanophyceae, Bacillariophyceae showed a clear seasonal evolution during 1998 (Fig. 6), while Dinophyceae and Cryptophyceae were less abundant but more homogeneously distributed during the year. 
Tab. 3. List of the most frequent phytoplankton taxa identified in Piburger See in 1998 with indication of the preferred season $(\mathrm{P}) ; \mathrm{W}=$ winter; $\mathrm{Sp} .=$ spring; $\mathrm{S}=$ summer, $\mathrm{A}=$ autumn; $\mathrm{Y}=$ all year round; $(\mathrm{N})=$ new taxon for Piburger See.

\begin{tabular}{|c|c|c|c|}
\hline CYANOPHYCEAE & $\mathrm{P}$ & НАРТОРНYСЕАЕ & $\mathrm{P}$ \\
\hline Aphanothece clathrata & $\mathrm{S}, \mathrm{A}$ & Chrysochromulina parva & $\mathrm{Sp}$ \\
\hline Chroococcus limneticus & S & & \\
\hline Cyanodictyon reticulatum & $\mathrm{S}$ & BACILLARIOPHYCEAE & $\mathrm{P}$ \\
\hline Lyngbia limnetica & A & Cyclotella spp. & $\mathrm{S}$ \\
\hline Microcystis incerta & $\mathrm{S}$ & Synedra sp. (S. acus group) & W \\
\hline \multirow[t]{2}{*}{ Snowella litoralis } & $\mathrm{S}$ & & \\
\hline & & CHLOROPHYCEAE & \\
\hline CRYPTOPHYCEAE & & Ankistrodesmus cf. falcatus & $\mathrm{Sp}, \mathrm{S}$ \\
\hline Cryptomonas marssonii & $\mathrm{Y}$ & Botryococcus braunii & $\mathrm{S}, \mathrm{A}$ \\
\hline Cryptomonas platyuris & $\mathrm{W}, \mathrm{A}$ & Chlamydomonas minima & $\mathrm{Y}$ \\
\hline Cryptomonas cf. ovata & $\mathrm{Y}$ & Chlamydomonas passiva & $\mathrm{W}, \mathrm{Sp}$ \\
\hline Cryptomonas cf. obovata & $\mathrm{Y}$ & Chlamydomonas sp.I & $\mathrm{Sp}$ \\
\hline Katablepharis cf. ovalis & $\mathrm{W}, \mathrm{A}$ & Chlamydomonas sp. II & $\mathrm{Sp}$ \\
\hline Katablepharis sp. (N) & A & Crucigenia tetrapedia & $\mathrm{Y}$ \\
\hline \multirow[t]{2}{*}{ Rhodomonas minuta } & A & Crucigeniella pulchra & $\mathrm{W}$ \\
\hline & & Elakatothrix gelatinosa & $\mathrm{Sp}$ \\
\hline DINOPHYCEAE & & Elakatothrix genevensis & $\mathrm{W}, \mathrm{Sp}$ \\
\hline Gymnodinium cf. albulum & $\mathrm{W}, \mathrm{A}$ & Eutetramorus fotti $(\mathrm{N})$ & $\mathrm{S}$ \\
\hline Gymnodinium uberrimum & $\mathrm{W}, \mathrm{A}$ & Monoraphidium miniumum & $\mathrm{Y}$ \\
\hline Peridinium cinctum & $\mathrm{Sp}, \mathrm{S}$ & Oocystis parva & $\mathrm{Y}, \mathrm{W}$ \\
\hline Peridinium willei & $\mathrm{W}, \mathrm{Sp}$ & Scenedesmus cf. pseudodenticulatus & W \\
\hline \multirow[t]{2}{*}{ Sphaerodinium sp. } & $\mathrm{Sp}$ & Scenedesmus heimii & $\mathrm{Y}$ \\
\hline & & Tetrachlorella incerta & $\mathrm{Sp}$ \\
\hline CHRYSOPHYCEAE & & Tetraedron minimum & $\mathrm{W}$ \\
\hline Chromulina parvula & $\mathrm{Sp}, \mathrm{S}$ & Tetrastrum komarekii & $\mathrm{Sp}$ \\
\hline Chrysococcus rufescens & S & Tetrastrum tenuispinum & $\mathrm{Sp}$ \\
\hline Chrysolykos skujae & W & Thorakochloris nygardii & $\mathrm{S}$ \\
\hline Chrysolykos planctonicum $(\mathrm{N})$ & W & Willea irregularis & A \\
\hline Dinobryon divergens & $\mathrm{Sp}$ & & \\
\hline Dinobryon cf. sociale & $\mathrm{Sp}$ & ZYGNEMALES & \\
\hline Mallomonas akrokomos & $\mathrm{S}$ & Cosmarium asterosporum & $\mathrm{Sp}$ \\
\hline Mallomonas crassisquama & $\mathrm{Sp}, \mathrm{S}$ & Cosmarium depressum var. planctonicum & $\mathrm{Y}$ \\
\hline Pseudokephyrion cf. entzii & $\mathrm{Y}$ & & \\
\hline Stichogloea doederleinii & $\mathrm{Sp}, \mathrm{S}$ & EUGLENOPHYCEAE & \\
\hline Uroglena $\mathrm{cf}$. nygardii & $\mathrm{S}$ & Euglena cf. acus & $\mathrm{S}, \mathrm{A}$ \\
\hline
\end{tabular}

Under winter ice cover (Figs 6 and 7A), the phytoplanktonic community of Piburger See was characterised by high relative abundance (up to $45 \%$ in February) of small coccal Chlorophyceae, like Oocystis parva W. \& G. S. West, Scenedesmus heimii Bourrelly, Scenedesmus pseudodenticulatus Hegewald \& Schnepf, Crucigenia tetrapedia (Kirchn.) W. \& G. S. West and Crucigeniella apiculata (Lemmermann) Komárek (Tab. 3). Chlorophyceae were accompanied by flagellated algae belonging mainly to the groups of Cryptophyceae (Cryptomonas marssonii Skuja, C. obovata Skuja and C. ovata Ehrenberg) and of Chrysophyceae (Chrysolykos planctonicus and C. skujai (Ramberg) Bourrelly. Diatoms, including Tabellaria flocculosa (Roth) Kützing and some Synedra Kützing species, reached an abundance of $c a 14 \%$ only in January at $3 \mathrm{~m}$ depth (Fig. 7A).

The spring period (from March to May) was characterised by a clear and progressive increase of the Chrysophyceae, which reached their absolute highest abundance in May (36\%, Fig. 6). This increase was related to the development of colonial taxa (like Dino- bryon divergens Imhof, D. sociale Ehrenberg and Stichogloea doederleinii (Schmidle) Wille), of large taxa (Mallomonas crassisquama (Asmund) Fott) and finally of small but very numerous Chromulina Cienkowski species. As a characteristic during spring was also the presence of Chrysochromulina parva Lackey, the unique taxon found within the Haptophyceae (Tab. 3), which reached its maximum abundance $(2.4 \%$, included in the group "others" in Fig. 6) in May 1998, with ca 3.4 $10^{6}$ cells $1^{-1}$. A similar temporal distribution of these two algal groups had been highlighted in all the previous studies (Findenegg 1968; Rott 1983; Prader 1993; Ebner 1994).

During summer 1998, the algal community of Piburger See was characterised by rapid changes from month to month. The centric diatom Cyclotella spp. (Kützing) Brébisson was clearly dominant in July (weighted mean relative abundance of $62 \%$, Fig. 6 , and maximum abundance of $89 \%$ at $0 \mathrm{~m}$, Fig. 7C). In August, diatoms decreased in abundance (to 9\%) and were replaced by Cyanophyceae belonging to the order Chroococcales (weighted mean relative abundance of 


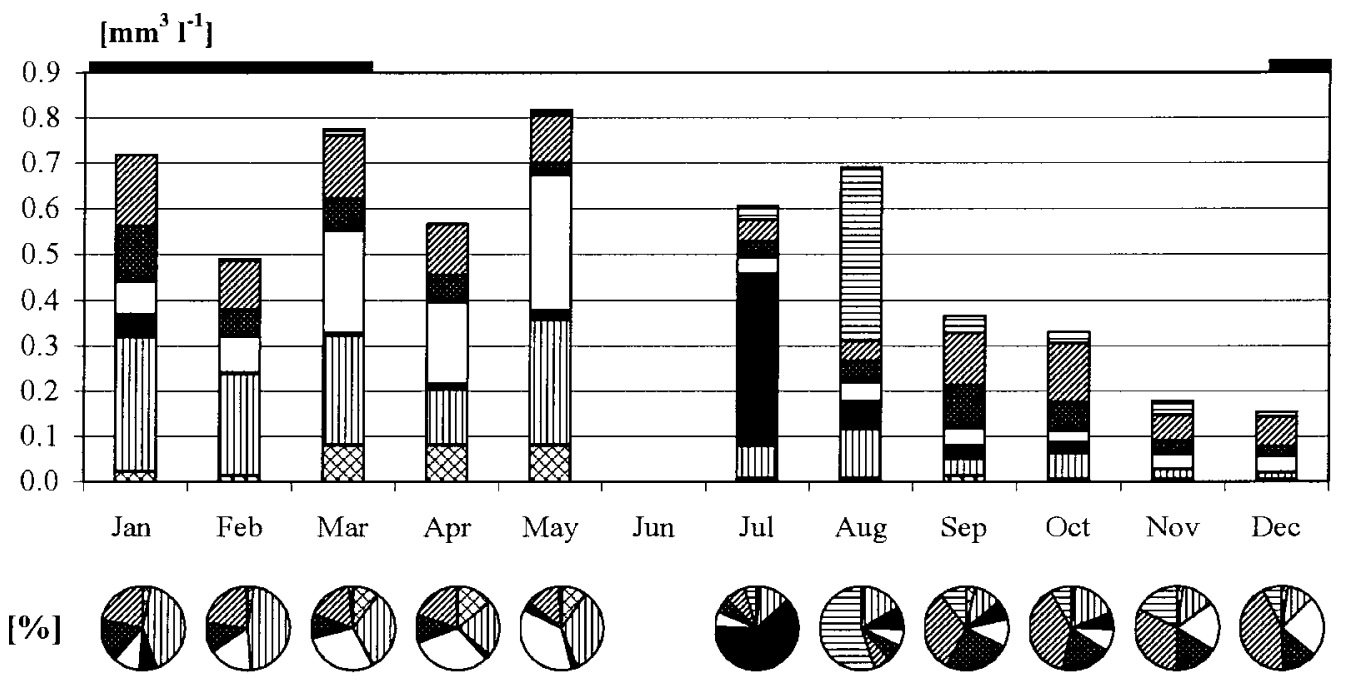

$\begin{array}{lll}\text { 目Cyanophyceae } & \text { Cryptophyceae } & \text { Dinophyceae } \\ \square \text { Chrysophyceae } & \square \text { Bacillariophyceae } & \mathbb{m} \text { Chlorophyceae } \\ \text { O Others } & & \end{array}$

Fig. 6. Phytoplankton biovolume in Piburger See in 1998: columns = weighted averages; pie charts $=$ relative abundances; $\mathbf{C}=$ ice cover.
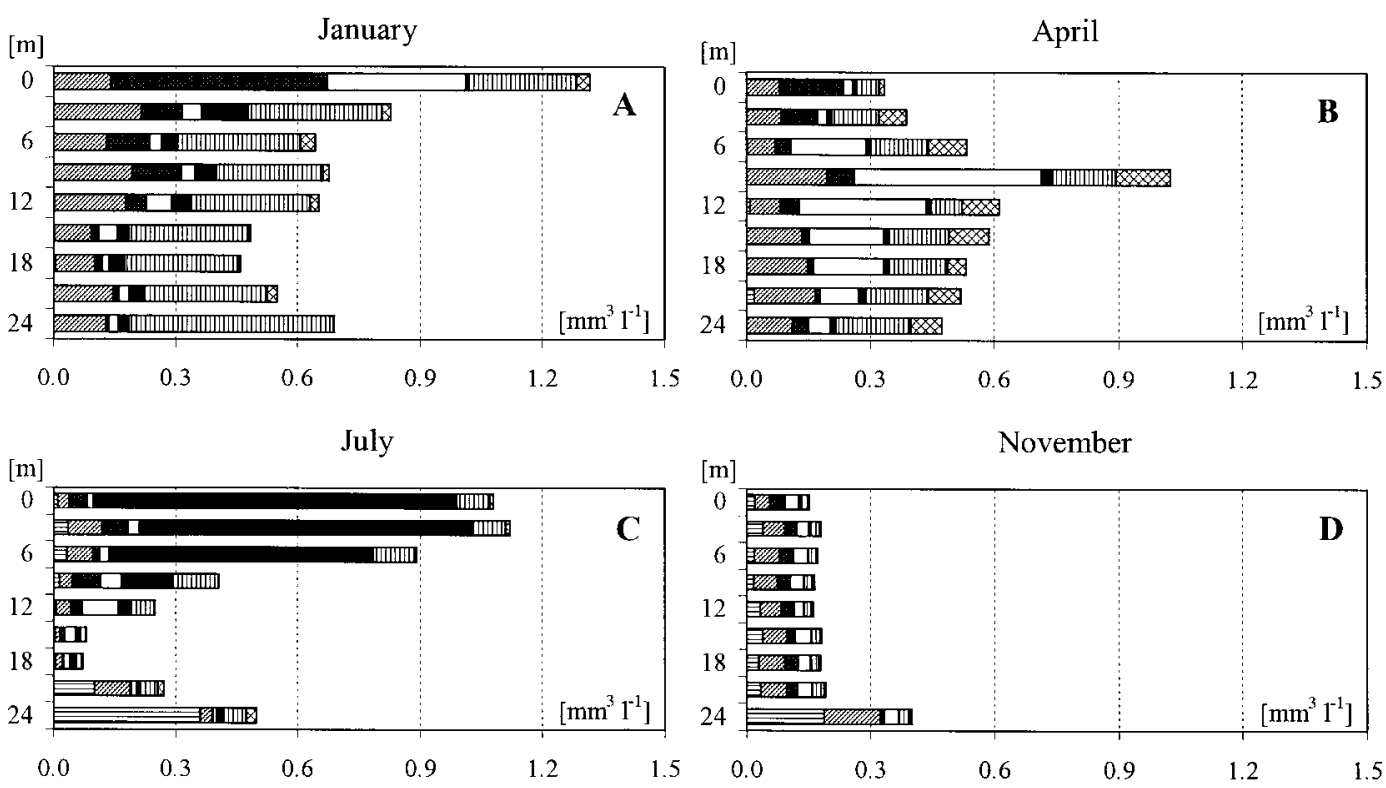
目Cyanophyceae
圈 Cryptophyceae
Dinophyceae
$\square$ Chrysophyceae
Bacillariophyceae $\quad$ Cllorophyceae
Others

Fig. 7. Vertical distribution of phytoplankton biovolume in Piburger See in four selected months of 1998.

55\%, Fig. 6), like Snowella litoralis, Aphanothece clathrata, Microcystis incerta. In September Cyanophyceae accounted to a relative abundance of only $\mathrm{ca} 10 \%$ (Fig. 6). The diatom bloom that occurred in July was accompanied by a pronounced decrease in the silica concentration (Psenner et al. 1998, 2000), which was already detected in June 1998 (Fig. 4C).

The progressive decrease in phytoplankoton biovolume observed in Piburger See during autumn 1998 (September - December 1998) was due mainly to the 
decrease in the abundance of Cyanophyceae, Dinophyceae and Chlorophyceae. No significant changes in the species assemblage occurred during this period.

The phytoplankton of Piburger See in 1998 showed a distinct vertical distribution, which appears to be related mainly to the adaptation of the different algal groups to changes in light climate, water temperature and nutrient concentrations. The reduced light intensity during winter led to a clear maximum of phytoplankton biovolume ( $c$ a $1.3 \mathrm{~mm}^{3} \mathrm{l}^{-1}$ ) under the ice cover in January 1998 (Fig. 7A). This maximum was due mainly to Dinophyceae (41\%) and Chrysophyceae (26\%). Nonmotile algae like coccal Chlorophyceae and Bacillariophyceae were more uniformly distributed along the water column in winter. The uniform vertical distribution of Cryptophyceae even in winter (mean relative abundance of $22 \%$, Fig. 7A) is due not only to their motility, but also to their adaptation to low light intensity (Reynolds 1997; Pipp \& Rott 1995) and to their mixotrophic capability (Rohde et al. 1966; Reynolds 1997). Because of these adaptative abilities, Cryptophyceae were the algal group in Piburger See which exhibited the least pronounced seasonal variability in species composition and biovolume (Figs 6 and 7).

With the reduction in ice thickness since February 1998, Chrysophyceae started a progressive shift towards the deeper water layers, reaching their maximum biovolume at $9 \mathrm{~m}$ depth in April $\left(0.45 \mathrm{~mm}^{3} \mathrm{l}^{-1}\right.$ Fig. $\left.7 \mathrm{~B}\right)$ and May $1998\left(0.57 \mathrm{~mm}^{3} \mathrm{l}^{-1}\right)$. This movement can be explained as a consequence of the adaptation of the algae to the darkness developed during winter under the ice cover (Pechlaner 1971b). A spring phytoplankton maximum between 9 and $15 \mathrm{~m}$ due to flagellated Chrysophyceae is characteristic of Piburger See, as highlighted in all previous investigations (Findenegg 1968; Rott 1983; Prader 1993; Pipp \& Rott 1995). Dinophyceae did not show a similar vertical shift, because the most abundant taxa of this group in Piburger See, like Gymnodinium uberrimum, Peridinium willei Huitfels-Kaas and Sphaerodinium sp. Woloszyńska, show distinct phototrophic behaviour (Rott 1988).

Water temperature displayed its determining role on phytoplankton vertical distribution especially during the summer stratification, when the phytoplankton was concentrated in the epilimnion (0-12 m, Fig. 7C). The high abundance of Cyanophyceae recorded in July 1998 below the depth of $20 \mathrm{~m}$ (up to $72 \%$ at $24 \mathrm{~m}$, Fig. 7C) was due to taxa without gas vesicles, like Aphanothece clathrata and Microcystis incerta.

The scarce correspondence between phytoplankton biovolume and chlorophyll $a$ concentration observed in July and August near the lake surface (compare Figs 5A and 7C) may be explained by a decrease in the relative chlorophyll content of the algae, in order to avoid overexcitation of the light harvesting complexes within the chlorophyll under an excessive level of irradiance (Reynolds 1997; Pipp \& Rott 1995). In a similar way the high chlorophyll concentrations recorded in the hypolimnion in late summer (Fig. 5A) could be related to the development of filamentous blue-green algae (Fig. 7C), which are characterised by higher content of pigments (Rott 1976).

During the autumn overturn (late October to late November 1998) the phytoplankton of Piburger See was homogeneously distributed along the water column (Fig. 7D). However, an effect of the phytoplankton vertical redistribution due to the ice on was detectable already in December 1998 (Psenner et al. 2000).

\section{DISCUSSION}

The physico-chemical characteristics of Piburger See in 1998 were in accordance with the results of monitoring activities carried out at the lake during the previous decade (Psenner et al. 1994, 1998, 2000). Conductivity and major ion concentrations reflect the geochemical characteristics of the catchment and show minor variability if compared to the past (Psenner et al. 1994). Nutrient concentrations show more pronounced changes, which we relate both to the effects of lake restoration measures and to the long-term changes in the phytoplankton biomass (Fig. 2C).

At Piburger See, effects of restoration measures on nutrient concentrations and phytoplankton biovolume were delayed by approximately two decades (Rott 1983; Pipp \& Rott 1995) as they became evident only since the late 1980s (Fig. 2). The increase of phytoplankton biovolume, chlorophyll a and TP concentrations, as observed after the installation of the Olszewski tube (Fig. 2 ), is considered as a short-term negative effect of deep water siphoning, as it has been observed in other eutrophied lakes, where reduction of algal biovolume and TP occurred only several years after restoration measures had been undertaken (Livingstone \& Schanz 1994).

In the case of Piburger See, the delayed recovery is considered to be a consequence of a strong internal nutrient loading (Pechlaner 1979). As documented in other lakes (Ahlgren 1977; Schindler et al. 1977) currents created by the suction of the Olszewski tube near the lake bottom may enhance nutrient regeneration from the sediment. The increased abundance of Oscillatoria limosa since 1970 was likely stimulated by the nutrient enrichment in the sediments during the eutrophication stage of Piburger See (Rott 1976). This effect could have contributed to the enhanced nutrient transport from sediments to the open water (Pechlaner 1979; Rott 1986), thus reducing an efficient nutrient removal through the Olszewski tube. The extended recovery period of the lake's trophic state may also be related to the delay in reduction of the diffuse nutrient load from a septic tank of the bathing station situated on the lake shore (Psenner et al. 1984) and to the very slow decrease in the annual mean TP concentrations in the main lake inlet (Fig. 2A). 
At present Piburger See can be considered as oligomesotrophic (Figs 1 and 2), according to TP and chlorophyll- $a$ concentrations, Secchi depth (Vollenweider \& Kerekes 1982) and summer phytoplankton biovolume (Heinonen 1980; Rott 1984). The oligotrophic status is supported by some characteristics of the phytoplankton assemblage, like the development of Chrysophyceae in spring and of small Cyclotella species in summer, and the abundance of mucilage-bound, non motile colonial Chlorophyceae during the whole year (Reynolds 1997).

Cryptophyceae, Chrysophyceae, Dinophyceae and Haptophyceae are in general more tolerant with respect to nutrient concentration and show very little change in comparison to the past (Findenegg 1968; Rott 1983; Prader 1993). The most evident variations concern the observed disappearance of the filamentous Cyanophycean Oscillatoria limosa from the phytoplankton samples since the late 1980's and the dominance of small centric Bacillariophyceae in the epilimnion in mid summer since the beginning of the 1990's (Prader 1993; Ebner 1994).

Several Cyclotella species (as C. radiosa, C. stelligera and $C$. pseudostelligera) have been regularly observed in the phytoplankton samples from Piburger See since the early investigations (Findenegg 1968; Rott 1983). However, centric diatoms are described as scarce along the whole water column throughout the year (Rott 1983). On the contrary, some Synedra species, belonging to the S. ulna (Nitzsch) Ehrenberg group, are reported as abundant in late winter and early spring in association to the meta-/hypolimnetic maxima of Oscillatoria limosa (Rott 1976). A strong development of Synedra ulna is reported in the literature (Hustedt 1930) as typical of waters with high nutrient concentrations which may be derived from algal decay. During 1998, Synedra showed a relative abundance of $14 \%$ once in January at $3 \mathrm{~m}$ depth (Fig. 7A), while Cyclotella was clearly dominant in the whole epilimnion in July (Fig. 7C).

A shift from filamentous blue green algae to small centric diatoms and coccal green algae has been often observed in small eutrophicated lakes after similar restoration measures elsewhere (Hickel 1978; Steinberg \& Schrimpf 1982). However, the scarcity of phytoplankton data during the last 10 years and the high inter-annual variability of the summer phytoplankton of Piburger See (Rott 1983; Pipp \& Rott 1995) do not allow stating whether the present phytoplankton assemblage represents a new stage in the ecosystem development of the lake.

Long term changes in the seasonal evolution of phytoplankton biovolume and assemblage in Piburger See might have been influenced as well by variations of local weather conditions and large scale climatic factors. Weighted monthly averages of phytoplankton biovolume, chlorophyll- $a$ and of related variables - as total nitrogen (TN) and TP concentrations in the lake - are significantly correlated with monthly means of air temperature and precipitation measured at the meteorological station of Ötz ( $820 \mathrm{~m}$ a.s.l., located near the lake in the Ötz Valley) during the reference period 1966 to 1999 (Tab. 4). The relation between phytoplankton biomass and weather conditions is shown also by the significant correlation between monthly weighted averages of phytoplankton biovolume and monthly weighted values of water temperature $(r=0.191, n=236)$, where the latter is clearly affected by both air temperature $(\mathrm{r}=$ $0.904, \mathrm{n}=298)$ and amount of precipitation $(\mathrm{r}=580, \mathrm{n}$ $=298)$. The inverse significant correlation between TP in the lake-inlet (Fig. 2A) and lake water temperature (r $=-0.158, \mathrm{n}=285$, Tab. 4) indicates that high lake-inlet TP concentrations are related to snowmelt periods (Psenner et al. 1998, 2000). However, lake-inlet TP does not seem to be correlated to available climatic factors as air temperature and precipitation (Tab. 4).

In spite of these relationships, no major long-term trends have been detected for regional climatic conditions, as confirmed by the generally slight deviations of annual mean air temperature and precipitation from average values of the period 1961-1999 (Fig. 8). On the contrary, a slight decrease in the ice-cover duration was noticed during the last two decades due to later ice on in December (Psenner et al. 1994).

The potential impact of large-scale climatic changes was tested considering the winter values of the North Atlantic Oscillation (NAO) index in the last 30 years (Jones et al. 1997). For a long-term data set of eighty years, Livingstone and Dokulil (2001) revealed appreciable correlations between the winter NAO index (December-March) and the monthly mean lake surface temperatures of low-lying lakes in Austria. However, we could not find a significant correlation for Piburger See between the winter NAO index and weighted averages of epilimnetic water temperature of the next spring $(\mathrm{r}=0.030, \mathrm{p}<0.05, \mathrm{n}=25)$. We relate this result to the strength of the regional winter climate, i.e. the regular presence of a lake ice cover from December through March, as hypothesized by Livingstone and Dokulil (2001). Similarly, we found insignificant $(p<0.05)$ correlations between winter NAO and spring (May through June) weighted mean values of TP $(\mathrm{r}=-0.148, \mathrm{n}=25)$, $\mathrm{NO}_{3}-\mathrm{N}(\mathrm{r}=-0.181, \mathrm{n}=16)$, Secchi depth $(\mathrm{r}=-0.338, \mathrm{n}=$ $33)$, chlorophyll- $a(\mathrm{r}=0.116, \mathrm{n}=22)$ and phytoplankton biovolume $(\mathrm{r}=0.032, \mathrm{n}=20)$. We chose to relate the winter NAO index to average values of the lake parameters measured in late spring, considering that the maximum phytoplankton biomass occur in Piburger See typically in the period from May to June (Rott 1983; Pipp \& Rott 1995).

The only significant correlation between large scale climatic trends and environmental parameters of Piburger See was observed between winter NAO and oxygen-saturation in the epilimnion (0-12 m) during spring $(\mathrm{r}=0.405, \mathrm{p}<0.01, \mathrm{n}=32)$. However, oxygen 
Tab. 4. Correlation matrix for monthly averages of the available climatic factors measured at the meteorological station of Ötz ( 820 $\mathrm{m}$ a.s.l.) and for physico-chemical and biological parameters measured at Piburger See in the period 1966-1999. Number of cases are reported in brackets, significant $(\mathrm{p}<0.01)$ correlation coefficients in bold. $*=$ significant at probability level $<0.05$.

\begin{tabular}{|c|c|c|c|c|c|c|c|c|c|c|}
\hline & & $\begin{array}{l}\mathrm{T} \text { (air) } \\
\left({ }^{\circ} \mathrm{C}\right)\end{array}$ & $\begin{array}{l}\text { Precipitation } \\
\quad(\mathrm{mm})\end{array}$ & $\begin{array}{c}\mathrm{T} \text { (water) } \\
\left({ }^{\circ} \mathrm{C}\right)\end{array}$ & $\begin{array}{c}\text { TP (inlet) } \\
\left(\mu \mathrm{g}^{-1}\right)\end{array}$ & $\begin{array}{c}\text { TP (lake) } \\
\left(\mu \mathrm{g}^{-1}\right)\end{array}$ & $\begin{array}{c}\mathrm{TN} \\
\left(\mu \mathrm{g}^{-1}\right)\end{array}$ & $\begin{array}{l}\mathrm{SiO}_{2} \\
\left(\mathrm{mg} \mathrm{l}^{-1}\right)\end{array}$ & $\begin{array}{l}\text { Chl- } a \\
\left(\mu \mathrm{g}^{-1}\right)\end{array}$ & $\begin{array}{l}\text { Phyto biovol. } \\
\qquad\left(\mathrm{mm}^{3} \mathrm{l}^{-1}\right)\end{array}$ \\
\hline $\mathrm{T}$ (air) & $\left({ }^{\circ} \mathrm{C}\right)$ & 1 & & & & & & & & \\
\hline Precipitation & $(\mathrm{mm})$ & $\mathbf{0 . 5 9 1}(408)$ & 1 & & & & & & & \\
\hline $\mathrm{T}$ (water) & $\left({ }^{\circ} \mathrm{C}\right)$ & $\mathbf{0 . 9 0 4}(298)$ & $\mathbf{0 . 5 8 0}(298)$ & 1 & & & & & & \\
\hline TP (inlet) & $\left(\mu \mathrm{g} \mathrm{l}^{-1}\right)$ & $-0.074(283)$ & $-0.086(283)$ & $\mathbf{- 0 . 1 5 8}(285)$ & 1 & & & & & \\
\hline TP (lake) & $\left(\mu \mathrm{gl}^{-1}\right)$ & $\mathbf{0 . 2 7 1}(298)$ & 0.189 (298) & $\mathbf{0 . 1 6 7}(300)$ & $\mathbf{0 . 1 7 1}(300)$ & 1 & & & & \\
\hline $\mathrm{TN}$ & $\left(\mu \mathrm{g}^{-1}\right)$ & $\mathbf{- 0 . 3 3 5}(177)$ & $\mathbf{- 0 . 2 3 5}(177)$ & $\mathbf{- 0 . 5 0 0}(179)$ & $\mathbf{0 . 2 5 2}(179)$ & $\mathbf{0 . 1 8 5}(179)$ & 1 & & & \\
\hline $\mathrm{SiO}_{2}$ & $\left(\mathrm{mg} \mathrm{l}^{-1}\right)$ & $0.165(19)$ & $-0.013(19)$ & $-0.132(21)$ & $0.369(21)$ & 0.494* (21) & $\mathbf{0 . 5 1 6}^{*}(21)$ & 1 & & \\
\hline Chl $-a$ & $\left(\mu \mathrm{g}^{-1}\right)$ & $\mathbf{0 . 3 2 9}(155)$ & 0.134 (155) & $0.061(155)$ & $-0.066(100)$ & $\mathbf{0 . 5 9 0}$ & $0.115(51)$ & $\mathbf{0 . 2 3 0}(11)$ & 1 & \\
\hline Phyto biovol. & $\left(\mathrm{mm}^{3} \mathrm{l}^{-1}\right)$ & $\mathbf{0 . 3 1 9}$ & $0.193(236)$ & $0.191(236)$ & $-0.058(236)$ & $\mathbf{0 . 4 6 1}(113)$ & $0.063(103)$ & $0.095(21)$ & $0.771(115)$ & 1 \\
\hline
\end{tabular}
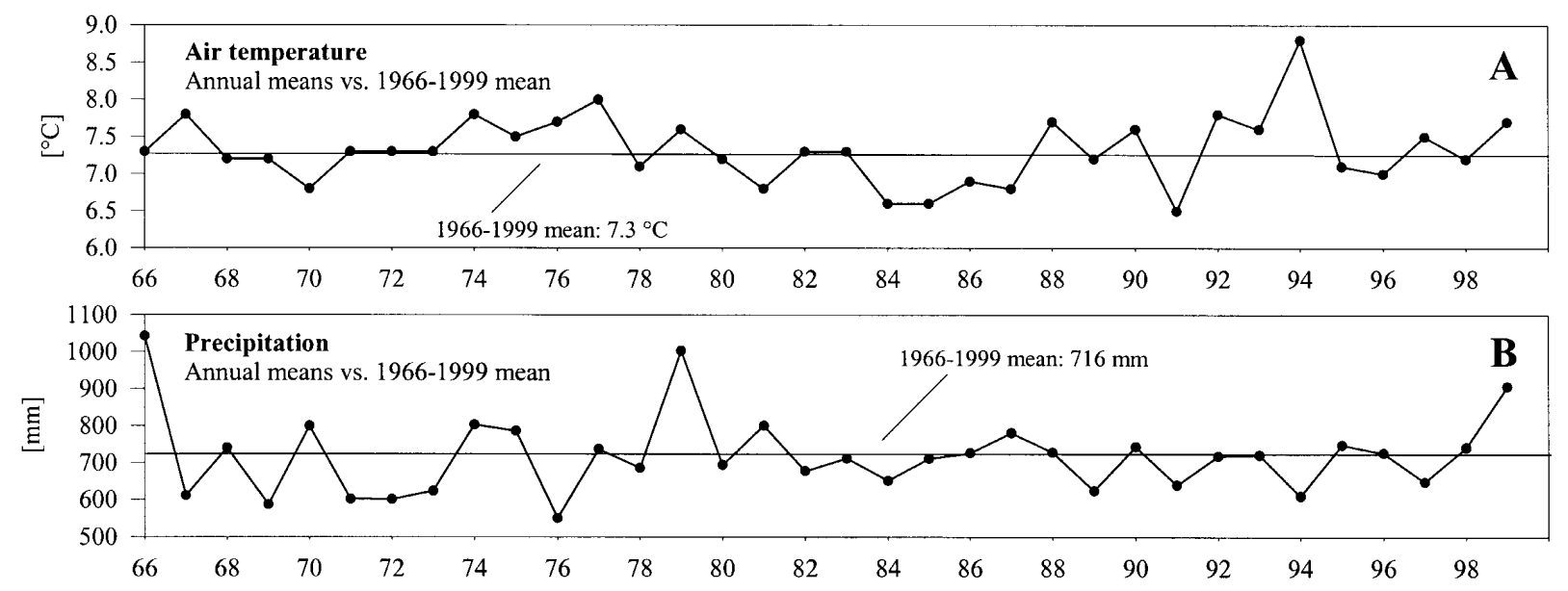

Fig. 8. Long term trends of weather conditions measured at the meteorological station of Ötz (820 m a.s.1., Ötz Valley) from 1966 to 1999.

saturation in the epilimnion of Piburger See does not appear to be significantly affected by algal growth, expressed by chlorophyll concentration and phytoplankton biovolume (Rott 1983).

According to George \& Taylor (1995) NAO effects on lake water chemistry and aquatic biological communities are much more pronounced in western and lowland European regions, while in mountain regions of central Europe, like the Alps, local climatic dynamics tend to prevail. The reduced influence of the large scale climatic events on local weather conditions in the Alps was confirmed by the absence of any significant correlation between winter NAO values and both mean annual air temperature and precipitation for the period 1961-1990, measured at the meteorological station of Ötz (820 m a.s.1.).

As no clear relation could be highlighted between either local weather condition or global climate and lake chemistry, the most likely driving factors for the changes in the phytoplankton community of Piburger See seem to be the slow but progressive decrease in the nutrient concentration that has occurred in the lake since late 1980s (Fig. 2).

\section{CONCLUSIONS}

The difficulties experienced in the interpretation of long-term trends within the phytoplankton of Piburger See emphasises the importance of detailed and regular investigations on both physico-chemistry and biology, with particular attention to seasonal evolution of chlorophyll concentration, phytoplankton biovolume and species assemblage.

An improved understanding of phytoplankton dynamics in Piburger See will support the discrimination between inter-annual variability and long-term trends of the trophic evolution of the lake. This aspect appears to be very important, when considering the complexity of the response of Piburger See to the lake restoration measures. The regular and detailed monitoring of water quality and trophic evolution of Piburger See has also a socio-economic impact, because of its great importance to tourism in Tyrol.

\section{ACKNOWLEDGMENTS}

The present study was supported by the EU project REFLECT (ENV4-CT97-0453), the Austrian Ministry 
of Science and the Community of Ötz. We would like to express our gratitude to Prof. Dr. Roland Psenner, Prof. Dr. Eugen Rott and Dr. Eveline Pipp (University Innsbruck) for the possibility to use the long term chemical and biological data series collected at Piburger See during the last 30 years, and to our colleagues Josef Franzoi and Werner Müller (University Innsbruck) for sampling and chemical analyses. We are indebted to the Austrian Meteorological Service and the Tyrolean Hydrographic Service for supplying partially unpublished meteorological data.

\section{REFERENCES}

Ahlgren, I. 1977. Role of the sediments in the process of recovery of an eutrophicated lake. In: H.L. Golterman (Ed.), Interactions between sediments and freshwater. Dr. W. Junk B.V., The Hague: 372-377.

Ebner, S. 1994. Diurnalität des Phytoplanktons (Biovolumen, Chlorophyllgehalt, Wachstumraten) im Rahmen der Modelluntersuchung mikrobieller Nahrungsnetze (1992/93). Diplomarbeit, Universität Innsbuck: 96 pp.

Findenegg, I. 1968. Das Phytoplankton des Piburger Sees im Jahre 1966. Ber. Nat.-med. Ver. Innsbruck, 56: 163-176.

Gattermayr, W. 1981. Das hydrographische Regime des Piburger Sees im Lichte 7 jähriger Meßergebnisse. J.-Ber. Abt. Limnol. Innsbruck, 7: 25-30.

George, D. G. \& A. H. Taylor. 1995. UK lake plankton and the Gulf Stream. Nature, 378: 139.

Heinonen, P. 1980. Quantity and composition of phytoplankton in Finnish inland waters. Publ. Water Res. Inst., 37, Vesihallitus-National Board of Waters, Finland.

Hickel, B. 1978. Phytoplankton-Sukzessionen in Grebiner See während einer künstlichen Belüftung des Hypolimnios. Arch. Hydrobiol., 82: 216-230.

Hustedt, F. 1930. Die Kieselagen Deutschlands, Österreichs und der Schweiz. Rabenhorst's Kryptogamentflora Bd VII. Akad. Verlges. Leipzig: 932 pp.

Jeffrey, S.W. \& G.F. Humphrey. 1975. New spectrophotometric equations for determining chlorophyll $a, b, c_{l}$ and $c_{2}$ in higher plants, algae and natural phytoplankton. Biochem. Physiol. Pflanzen, 167: 191-194.

Jones, P.D., T. Jonsson \& D. Wheeler. 1997. Extension to the North Atlantic Oscillation using early instrumental pressure observations from Gibraltar and South-West Iceland. Int. J. Climatol., 17: 1433-1450.

Livingstone, D. \& F. Schanz. 1994. The effects of deep-water siphoning on a small, shallow lake: a long-term case study. Arch. Hydrobiol., 132: 15-44.

Livingstone, D. \& M. Dokulil. 2001. Eighty years of spatially coherent lake surface temperatures and their relationship to regional air temperature and the North Atlantic oscillation. Limnol. Oceanogr., 46: 1220-1227.

Lund, J.W.G., G. Kipling \& E.D. LeCren. 1958. The inverted microscope method for estimating algae number and statistical basis of estimating by counting. Hydrobiologia, 11: 143-170.

Mayrhofer, J. 1975. Chemismus (ausgenommen P, N und FeVerbindungen) und Thermie des Piburger Sees. J. -Ber. Abt. Limnol. Innsbruck, 1: 14-26.

Nickus, U., H. Thies, M. Kuhn \& R. Psenner. 1998. The snow cover at a headwater site in the Tyrolean Alps: seasonal and local variability of atmospheric trace substances in the snow pack. In: U. Tappeiner, F.V. Ruffini \& M. Fumai (Eds), Hydrology; Water Resources and Ecology of Mountain Areas. Poster Volume of Headwater '98, European Academy, Bolzano, Italy.

Pechlaner, R. 1968. Beschleunigte Eutrophierung im Piburger See, Tirol. Ber. Nat.-med. Ver. Innsbruck, 56: 143-161.
Pechlaner, R. 1971a. Die Restaurierung des Piburger Sees. Carinthia II. Sonderh., 31: 97-115.

Pechlaner, R. 1971b. Factors that control the production rate biomass of phytoplankton in high mountain lakes. Mitt. Internat. Verein. Limnol., 19: 125-145.

Pechlaner, R. 1979. Response of the eutrophied Piburger See to reduced external loading and removal of monimolimnic water. Arch. Hydrobiol. Beih. Ergebn. Limnol., 13: 293305.

Pipp, E. \& E. Rott. 1995. A phytoplankton compartment model for a small meromictic lake with special reference to species-specific niches and long-term changes. Ecological Modelling, 78: 129-148.

Prader, K. 1993. Die Entwicklung des Phytoplanktons im Sommer im Piburger See (Ötztal, Tirol). Ber. Nat.-med. Ver. Innsbruck, 80: 59-51.

Psenner, R., R. Pechlaner \& E. Rott. 1984. Belastung und Belastbarkeit des Piburger Sees. In: Der Einfluss des diffusen Nährstoffeintrags auf die Eutrophierung von Seen. Veröffentlichungen des Österreichischen MaBProgramms, 8(1), Universitätsverlag Wagner, Innsbruck.

Psenner, R. 1988. Alkalinity generation in a soft-water lake: watershed and in-lake processes. Limnol. Oceanogr., 33: 1463-1475.

Psenner, R., J. Moser., J. Franzoi \& W. Müller. 1994. Der limnologische Zustand des Piburger Sees 1994 im Licht langjähriger Veränderungen. Universität Innsbruck, Institut für Zoologie und Limnologie, Jahresbericht: $87 \mathrm{pp}$.

Psenner, R., J. Moser, J. Franzoi \& W. Müller. 1998. Limnologische Untersuchungen am Piburger See im Jahr 1998. Universität Innsbruck, Institut für Zoologie und Limnologie, Jahresbericht: 42 pp.

Psenner, R., M. Tolotti, H. Thies, J. Franzoi \& W. Müller. 2000. Limnologische Untersuchungen am Piburger See. Limnochemie im Jahr 1999. Phytoplankton im Jahr 1998. Universität Innsbruck, Institut für Zoologie und Limnologie, Jahresbericht: $66 \mathrm{pp}$.

Reynolds. C.S. 1997. Vegetation processes in the pelagic: a model for ecosystem theory. In: O. Kinne (Ed.), Excellence in Limnology, 9: $371 \mathrm{pp}$.

Rohde, W., J.E. Hobbie \& R.T. Wright. 1966. Phototrophy and heterotrophy in high mountain lakes. Verh. int. Ver. Limnol., 16: 302-313.

Rott, E. 1976. Ökologische Beobachtungen an der Blaualge Oscillatoria limosa Ag. im Piburger See (Tirol, Österreich). Ber. Nat.-med. Ver. Innsbruck, 63: 57-66.

Rott, E. 1981. Some results from phytoplankton counting intercalibration. Schweiz. Z. Hydrobiol., 43: 34-62.

Rott, E. 1983. Sind die Veränderungen im Phytoplanktonbild des Piburger Sees Auswirkungen der Tiefwasserableitung? Algological Studies, 34: 29-80.

Rott, E. 1984. Phytoplankton as biological parameter for the trophic characterization of lakes. Verh. int. Ver. Limnol., 22: $1078-1085$.

Rott, E. 1986. The light climate of a small deep lake (Piburger See, Austria) and its influence on phytoplankton production. Arch. Hydrobiol., 107: 89-117.

Rott, E. 1988. Some aspects of the seasonal distribution of flagellates in high mountain lakes. Hydrobiologia, 161: 159-160.

Rott, E. 1991. Langzeitentwicklung des Phytoplanktons im Piburger See seit 1969. - DGL Jahrestagung, Mondsee (Österreich), 30.9.-6.10. 1991: 27-31.

Schindler, D.W., R. Hesslein \& G. Kipphut. 1977. Interactions between sediments and overlying waters in an experimentally eutrophied Precambrian Shield Lake. In: H.L. Golterman (Ed.), Interactions between sediments and freshwater. Dr. W. Junk B.V., The Hague: 235-243.

Steinberg, C. \& A. Schrimpf. 1982. Auswirkung einer künstlichen Volldurchmischung auf das Geschehen im Fischkal- 
ter See (Osterseengebiet). Bayer. Landesamt. Wasserw., Beitr. Limnol. bayer. Seen. 1/82: 7-54.

The MOLAR Water Chemistry Group. 1999. The MOLAR Project: atmospheric deposition and lake water chemistry. In: V. Strakabova, C. Callieri \& J. Fott (Eds), Pelagic food web in mountain lakes. MOuntain LAkes Research Program. J. Limnol., 58: 88-106.

Thies, H. 2000. The importance of internal alkalinity generation for an acidified mountain lake as revealed by mass budgets. Silva Gabreta, 4: 9-104.

Thies, H., U. Nickus, \& R. Psenner. 1998. Response of discharge and water quality in headwater brooks on distinct hydroclimatic conditions in the Tyrolean Alps. IAHS Publ., 248: 491-497.

Received: March 2001

Accepted: March 2002
Thies, H., U. Nickus, C. Arnold, R. Schnegg, A. Wille, \& R. Psenner. 2000. Biogeochemistry of a high mountain lake in the Austrian Alps. Verh. int. Ver. Limnol., 27: 1-4.

Tilzer, B. 1972. Dynamik und Produktivität von Phytoplankton und pelagischen Bakterien in einem Hochgebirgssee (Vorderer Finstertaler See, Österreich). Arch. Hydrobiol., 3: 201-273.

Utermöhl, H. 1958. Zur Vervollkommung der quantitativen Phytoplanktonmethodik. Mitt. Internat. Ver. Limnol., 9: 138.

Vollenweider, R. A. \& J. Kerekes. 1982. Eutrophication of Waters, Monitring, Assessment and Control. OECD, Paris: $154 \mathrm{pp}$. 